\title{
A Conceptual Model for Group Support Systems in Local Councils
}

Conference or Workshop Item

Accepted Version

Harris, J. and Sun, L. (2008) A Conceptual Model for Group Support Systems in Local Councils. In: 10th International Conference on Enterprise Information Systems, 12-16 June 2008, Barcelona, Spain, pp. 203-207. Available at https://centaur.reading.ac.uk/1440/

It is advisable to refer to the publisher's version if you intend to cite from the work. See Guidance on citing.

Published version at: http://www.iceis.org

All outputs in CentAUR are protected by Intellectual Property Rights law, including copyright law. Copyright and IPR is retained by the creators or other copyright holders. Terms and conditions for use of this material are defined in the End User Agreement.

\section{www.reading.ac.uk/centaur}

\section{CentAUR}

Central Archive at the University of Reading

Reading's research outputs online 


\title{
A CONCEPTUAL MODEL FOR GROUP SUPPORT SYSTEMS IN LOCAL COUNCILS
}

\author{
Joycelyn Harris, Dr Lily Sun \\ School of Systems Engineering, University of Reading, Whiteknights, Reading, Berkshire, England \\ j.a.harris@ reading.ac.uk, lily.sun@ reading.ac.uk
}

Keywords: e-government, collaboration, group support systems, adaptability

\begin{abstract}
This paper proposes a conceptual model of a context-aware group support system (GSS) to assist local council employees to perform collaborative tasks in conjunction with inter- and intra-organisational stakeholders. Most discussions about e-government focus on the use of ICT to improve the relationship between government and citizen, not on the relationship between government and employees. This paper seeks to expose the unique culture of UK local councils and to show how a GSS could support local government employer and employee needs.
\end{abstract}

\section{INTRODUCTION}

This paper proposes a conceptual model for a context-aware group support system (GSS) to assist local council employees in performing collaborative tasks in council-led partnerships. The concepts modelled are goal, context, norm, and business process. This paper identifies the phenomena within UK local councils and the context in which employees work. 'Government' is an organisation that has the authority to make and enforce laws for a specified territory. E-government has been described as the intensive use of information technologies for the provision of public services, the improvement of managerial effectiveness and the promotion of democratic values. Collaborative public management (CPM) is the arrangement and agreement between two or more organisations to deliver government services. CPM is driven by a need for coordinated and more efficient service provision to provide a seamless service to citizens (Vangen and Huxham, 2003). Collaborative working allows private and public sector stakeholders to share resources, expertise, good practise, costs and risks in achieving their goals.

There has been much discussion about how egovernment benefits citizens, but less into how it can benefit government employees. E-collaboration is the use of electronic technologies by individuals to realise a common task (Kock, 2005). E-government in the form of a context-aware GSS would support collaborative working, could improve the efficiency of work and empower local council employees.

\section{UK LOCAL COUNCILS}

Government organisations differ from private organisations because they a face unique challenges due to their social obligations, higher legislative accountability and public accountability (Stemberger and Jaklic, 2007). A preliminary study of local councils within Berkshire, England was undertaken to uncover their unique context. This study was conducted through investigation of publications.

Local councils work in accordance with policy set by central government and within statutory and discretionary powers awarded by acts of parliament. They consist of elected councillors and full council elections are held every three or four years. Elections can have a direct impact on council employees because they are likely to lead to a change in a local council's goals and business processes.

Local councils produce strategies that are applicable to the local council as a whole or to a single organizational division. They state divisional goals, how goals are to be achieved, and the resources that will be required. These documents guide employee behaviour. Through a comparison of 
the strategies of local councils in Berkshire, England, a general pattern emerged (Figure 1).

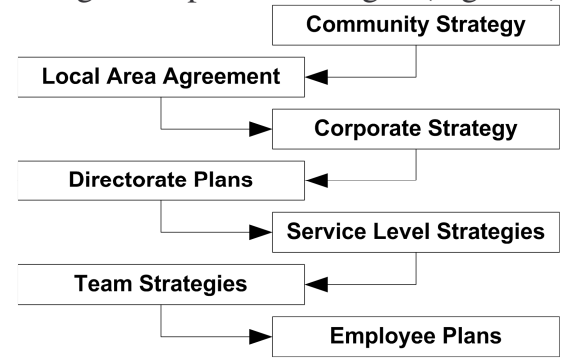

Figure 1: Pattern of strategy and plan development within local councils.

The top-most strategy is the Community Strategy. These are created by a partnership between the local council, community groups, authorities, voluntary organisations and private businesses. The community strategy is used to inform the development of a Local Area Agreement (LAA) and a Corporate Strategy. The LAA provides a framework within which local councils, other local organisations and government departments, work together to develop solutions to local problems (United Kingdom Parliament, 2006). It is an agreement between a council, its partners and central government about the priorities for local improvement. LAA targets are often linked to funding. Both the community strategy and LAA are statutory requirements (Her Majesty's Stationery Office, 2000).

The corporate strategy specifies the goals that the council will work towards. Its development is informed by the community strategy, the LAA, national, regional and local strategies, and recommendations from inspections. It will contain or refer to key documents that form strategies for council directorates, service departments and teams.

A 'directorate' is a high-level council division headed by a permanent officer. The names of the directorates vary across Berkshire local councils, but there are commonalities in service provision. The typical directorate divisions are:

- Chief Executive Office or Corporate Services

- Education

- Environment

- $\quad$ Finance, Procurement and Resources

- Leisure and Culture

- Children and Young People

- Social and Community Care

Many high-level goals cut across directorate boundaries and satisfying them requires individual employees to liaise with a large number of stakeholders that are external to their team. For example, the Environment, Culture and Sport directorate within Reading Borough Council works in partnership with 30 or more intra- and interorganisational stakeholders.

The business processes of local councils are subject to inspection and review by citizens within the electorate, councillors and central government. For example, each year central government sets out a number of measures called Best Value Performance Indicators (BVPI) that are designed to assess the progress of local councils against national priority areas. At the end of each financial year a local council to report:

1. 2006/07 performance against 2006/07 targets.

2. Brief explanation of any significant variances.

\section{RELATED RESEARCH}

Systems designed for commercial organisations are not ideally suited to meet the needs of government organisations because e-government is situated in an environment of distributed control and interdependency (Scholl, 2006). E-government has been categorised as government-to-government, government to citizen, government-to-business (G2B), government-to-civil societal organisations (G2CSO), and citizen-to-citizen (Brown and Brudney, 2003). The conceptual model will assist local council employees conducting G2B and $\mathrm{G} 2 \mathrm{CSO}$ business processes.

Business process systems in government organisations do not make full use of the advantages that IT can provide (Lu et al., 2004). Layne and Lee (2001) have defined a four-stage model of egovernment development:

1. Catalogue/presentation

2. Transaction

3. Vertical integration

4. Horizontal integration

Berkshire local councils have fulfilled stages 1 and 2. They all have a website providing a 'catalogue' of the services they have to offer and allow citizens to perform transactions via the internet. Stages 3 and 4 relate to the integration of scattered systems at different levels (vertical) and different functions (horizontal) of government services. Many institutional arrangements and organisational structures found in government contexts offer incentives for single-agency work. 
These structures can hinder inter-organisational information integration and, consequently, crossagency collaboration (Luna-Reyes et al., 2007). The degree of e-government adoption in UK local councils falls short of stages 3 and 4 . The Transformational Local Government paper states: "Much of our intelligence remains in organisational silos, however, or in the heads of individuals, and is not yet fully used" (Chief Information Office, 2006). No evidence was found to show that Berkshire local councils have reached stages 3 and 4; however, a more in-depth investigation might yield different results.

To achieve stages 3 and 4 organisational changes need to take place alongside technological changes. Government organisations are lacking in data standards that facilitate the sharing of government information (Lu et al., 2004). The UK government is addressing these issues by providing best practice guidance to government agencies, such as the EGovernment Interoperability Framework (Cabinet Office, 2005). The challenge of collaborating with the owners of the data to share information resources may require working across organisational boundaries and will have implications for change management, business-process reengineering and training (Lee and Kim, 2007, Luna-Reyes et al., 2007).

Organisational, social and political structures and attitudes are impeding the take up of e-collaboration systems because the values associated with these structures are regarded more highly than the benefits that e-collaboration systems could deliver. One impeding structural aspect is centralised hierarchies. Yet centralised hierarchies are less common in partnerships; they usually have a more decentralised and flatter structure (Vangen and Huxham, 2003), so e-collaboration systems may be ideally suited to support partnerships.

Partnerships are created because it is thought that working together will yield more benefits that working alone. To achieve collaborative advantage, there needs to be an appropriate interface to an between each partnership member that they can use to lead and represent their organisation in the partnership (Vangen and Huxham, 2003). A GSS aims to create efficient, effective and predictable pattern of working amongst a group (Chen et al., 2006) and to provide a shared representation of activities that the group performs (Moran et al., 2005). The main objectives of shared activity representation are:
- To guide, support and coordinate work, but not to overly constrain it.

- To provide a single place for people to manage the whole range of their activities.

- To capture, reuse and evolve best practices in activity patterns.

- To integrate informal business activities and workflow-driven business processes.

It is highly likely that partnership members are required to attend a number of face-to-face meetings. These are useful because they enhance project awareness, all partners are able to take part in discussions and negotiations, and decisions can be made together (Chen et al., 2006). However, meeting minutes may not be taken or maybe inaccurate and decision rationale may not be recorded. This can lead to business process problems for individual employees when the information they need to be able to perform a process (or to create a new process) is unknown to them or is unavailable (Weerakkody et al., 2006). An electronic information system, such as a content management system, can support organisational memory (Cegarra-Navarro et al., 2007, Raghu and Vinze, 2007). However even when a partner is in possession of information required to execute a process they still may not be familiar with it enough to be able to use it to achieve a goal (Vangen and Huxham, 2003). Including goal information for activities in process narratives could reduce decision-making difficulties. It may result in a better recall of process details, a greater confidence in solutions and a greater comprehension of the process (Kuechler and Vaishnavi, 2006).

Field and case studies indicated that efficiency and effectiveness was enhanced when using a GSS in comparison with face-to-face and manual methods (Fjermestad and Hiltz, 2000). Under certain circumstances, productivity and participant satisfaction can also be increased (Chen et al., 2006). However the high level of association between participation and effectiveness maybe due to results being based on perceptions of effectiveness rather than operational indicators of effectiveness (McCaffrey et al., 1995).

\section{CONCEPTUAL MODEL}

A GSS based on the conceptual model below (Figure 2) is proposed to support collaborative work 
in local council-led partnerships. Five concepts are modelled: goal, context, norm, and business process. A system based on this model will facilitate the communication and work conducted between middle managers, knowledge workers, and operational managers that are employed by local councils and the other partnership organisations.

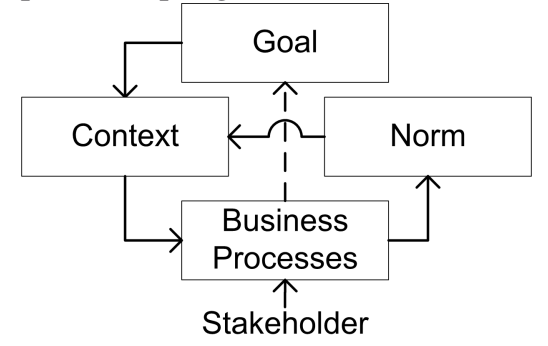

Figure 2: Conceptual model of an adaptable GSS.

Each council goal will be described using natural language. There will be a hierarchy of goals: the topmost being the council's LAA objectives, cascading down to service plan goals. Goals and contexts will be linked.

The context is the environment in which goalrelated activities take place, such as the directorate or team. Two types of change may take place within a local council that will affect context: change to the organisational structure, and change to priorities. These changes are likely to necessitate an adaptation to service provision and council goals. A change in the goals will also affect once more the context in which employees work.

A unique identification number will represent each organisational group in the system. The number will define the group's position in the council, as the numbers will be inherited and placed in a hierarchy:

1. Environment directorate

1.1 Highways and traffic department

1.1.1. Road safety team

Changes in goal and context will affect business processes and norms. A local council will want to adapt its existing processes and norms to these changes to prevent a lack of alignment between these items and to ensure that conflicting goals do not arise. A lack of alignment and conflicting goals will result in inefficient working practices. It may also result in employees not achieving council goals and targets, which could have an effect on the funding a council receives. This system will respond well to changes in the context in which it is used. The adaptation should be transparent in the sense that changes made to the file structure or content should be traceable back to their original configuration.

The specific procedures a local council needs to follow to achieve their goals could be described as norms. Norms in an information system (IS) prescribe the actions of components and may involve social rules, operational rules and standards. It is important to have a well-defined and managed collection of norms in an IS because they constitute its knowledge and guide its behaviour (Gan et al., 2007). Norms are dependent upon a context for their necessity, usefulness and application. There are six components to norms (Liu, 2000). The character of a norm prescribes whether it is mandatory, permissive or prohibitive. The content refers to the activity. The condition dictates when the norm should be applied. The agent that issues the norm is the authority, and those that can apply the norm are the subjects. Finally, the occasion refers to the time and space in which the norm is issued. A BVPI obligation could be expressed as:

Whenever <BVPI is due>

If $<2006 / 07$ targets are available $>$

Then <team or department>

Is <obliged>

To <compare 2006/07 targets with

2006/07 performance>

It is envisaged that the system will use norms in this manner to guide the activities of stakeholders.

Performing business processes will enable employees to achieve council goals. The business processes performed by stakeholders will be located in a space defined by contexts, norms and goals. This system area will be the interface to the majority of stakeholder-facing functions and features, which include:

- Electronic communication

- Documents management

- Goal management

Process narratives will include goal information to stimulate a greater comprehension of the process.

\section{CONCLUSION}

This paper introduced a conceptual model of a group support system to assist employees within a local council to work in collaborative partnerships. It provided an overview of research relating to the UK government, e-government provision and collaboration. The current state of local government in the UK has been examined, paying particular 
attention to the issues affecting local councils. A number of problems relating to e-government implementation and collaborative working have been discussed.

Further investigation is needed into the use and effectiveness of e-collaboration tools within UK local councils. Also needed is investigation to ascertain if UK government guidelines are vigorous enough to underpin vertical and horizontal integration. Future work will include identifying a partnership within a local council to case study in order to uncover its business processes, and to ascertain if a GSS based on the given conceptual model could make it more effective, according to perceptual and operational indicators.

\section{REFERENCES}

Brown, M. M. \& Brudney, J. L. (2003) Learning Organizations in the Public Sector? A Study of Police Agencies Employing Information and Technology to Advance Knowledge. Public Administration Review, $63,30-43$.

Cabinet Office (2005) e-GIF (e-Government Interoperability Framework). London, Govtalk.

Cegarra-Navarro, J. G., Jimenez, D. J. \& MartinezConesa, E. A. (2007) Implementing e-business through organizational learning: An empirical investigation in SMEs. International Journal of Information Management, 27, 173-186.

Chen, F., Briggs, R. O., Corbitt, G., Nunamaker Jr., J. F., Sager, J. \& Gardiner, S. C. (2006) Project Progress Tracking Template - Using a Repeatable GSS Process to Facilitate Project Process Management 39th Annual Hawaii International Conference on System Sciences (HICSS'06) Track 1. Hawaii IEEE Computer Society.

Chief Information Office (2006) Transformational Local Government - Discussion Paper. In Chief Information Office (Ed.), Cabinet Office,.

Fjermestad, J. \& Hiltz, S. R. (2000) Group support systems: A descriptive evaluation of case and field studies. Journal of Management Information Systems, 17, 115-159.

Gan, R., Xie, Y. \& Feng, H. (2007) Classification and Description of Norms in Information Systems with Requirement-driven Adaptive Architecture. IN LIU, K., CONNOLLY, J. \& O'NEILL, S. (Eds.) International Conference on Organisational Semiotics: Complexity in Organisational and Technological Systems. Sheffield, UK, Reading University.

Her Majesty's Stationery Office (2000) The Local Authorities (Functions and Responsibilities) (England) Regulations 2000. Her Majesty’s Stationery Office,.
Kock, N. (2005) What is E-Collaboration? International Journal of e-Collaboration, 1, i-vii.

Kuechler, W. L. \& Vaishnavi, V. (2006) So, Talk To Me: The Effect of Explicit Goals on the Comprehension of Business Process Narratives. MIS Quarterly, 30, 961A16.

Layne, K. \& Lee, J. (2001) Developing fully functional Egovernment: A four stage model. Government Information Quarterly 122-136.

Lee, J. \& Kim, J. (2007) Grounded theory analysis of egovernment initiatives: Exploring perceptions of government authorities. Government Information Quarterly, 24, 135-147.

Liu, K. (2000) Pragmatics and Communication. Semiotics in Systems Engineering. Cambridge, Cambridge University Press.

Lu, L., Zhu, G. \& Chen, J. (2004) An Infrastructure for EGovernment Based on Semantic Web Services. IEEE International Conference on Services Computing (SCC'04) IEEE Computer Society.

Luna-Reyes, L. F., Gil-Garcia, J. R. \& Cruz, C. B. (2007) Collaborative digital government in Mexico: Some lessons from federal Web-based interorganizational information integration initiatives. Government Information Quarterly.

Mccaffrey, D. P., Faerman, S. R. \& Hart, D. W. (1995) The Appeal and Difficulties of Participative Systems. Organization Science, 6, 603.

Moran, T. P., Cozzi, A. \& Farrell, S. P. (2005) Unified Activity Management: Supporting People in EBusiness. Communications of the ACM, 48, 67-70.

Raghu, T. S. \& Vinze, A. (2007) A business process context for Knowledge Management. Decision Support Systems, 43, 1062-1079.

Scholl, H. J. (2006) Electronic government: Information management capacity, organizational capabilities, and the sourcing mix. Government Information Quarterly, 23, 73-96.

Stemberger, M. I. \& Jaklic, J. (2007) Towards Egovernment by business process change--A methodology for public sector. International Journal of Information Management, 27, 221-232.

United Kingdom Parliament (2006) Local Area Agreements across England and the Future of LAAs.

Vangen, S. \& Huxham, C. (2003) Enacting Leadership for Collaborative Advantage: Dilemmas of Ideology and Pragmatism in the Activities of Partnership Managers. British Journal of Management, 14, S61-S76.

Weerakkody, V., Baire, S. \& Choudrie, J. (2006) EGovernment: The Need for Effective Process Management in the Public Sector. System Sciences, 2006. HICSS '06. Proceedings of the 39th Annual Hawaii International Conference on. 